\title{
Development and Pre-clinical Study of Anti- Allergic Cream Containing Dexamethasone and Chlorpheniramine
}

\author{
Deksametazon ve Klorfeniramin İçeren Anti-alerjik Kremlerin Geliştirilmesi \\ ve Klinik Öncesi Çalışması
}

\author{
(D) Duy Toan PHAM*, (D) Ngoc Nha Thao NGUYEN \\ Can Tho University of Medicine and Pharmacy, Faculty of Pharmacy, Department of Pharmaceutical Technology, Can Tho, Vietnam
}

\begin{abstract}
Objectives: In this study, we aimed to develop and optimize an anti-allergic cream containing dexamethasone and chlorpheniramine using the design of experiments (DoE) method. The optimized product was investigated for its physicochemical properties and in vivo therapeutic effects in rabbits.

Materials and Methods: The creams were formulated using the simple mixing process, which was optimized by the Design Expert software. The products were then evaluated the properties such as $\mathrm{pH}$, skin diffusion profile, short-term stability, qualitative, and assay, using the newly validated UV-Vis spectrophotoscopy quantitative method. In vivo efficacy tests in rabbits of the best products were compared with the marketed Phenergan ${ }^{\circledR}$ (promethazine $2 \%$ ).

Results: The UV-Vis method used to simultaneously determine the amount of both dexamethasone and chlorpheniramine was successfully developed and validated. Using the DoE method, it was clear that the release profile of dexamethasone depended on the amount of sodium lauryl sulfate, propylene glycol, and DMSO. In contrast, only DMSO affected the release pattern of chlorpheniramine. The best formulation was optimized by the software. The product showed acceptable parameters in $\mathrm{pH}(5.7 \pm 0.1)$, short-term stability over 10 days, and skin diffusion profiles of $20.47 \pm 1.25 \%$ and $4.92 \pm 0.42 \%$ after $40 \mathrm{~min}$ for dexamethasone and chlorpheniramine, respectively. In addition, the product demonstrated no observable inflammatory response in the experimental animals. Also, it illustrated 2 -fold better anti-allergic efficacy than the marketed product (i.e., 27.2 compared with 43.4 min in the recovery time).

Conclusion: We were successful in developing and optimizing an anti-allergic cream containing dexamethasone and chlorpheniramine. The best product satisfied all required parameters. Interestingly, our product showed higher efficacy than Phenergan ${ }^{\circledR}$. These results can be a background for further clinical trials.
\end{abstract}

Key words: Dexamethasone, chlorpheniramine, allergic, design of experiments, in vivo study

Öz

Amaç: Bu çalışmada deney tasarımı (DoE) yöntemi kullanılarak deksametazon ve klorfeniramin içeren anti-alerjik kremlerin geliştirilmesi ve optimize edilmesi amaçlandı. Optimize edilen ürünün, tavşanlarda fizikokimyasal özellikleri ve in vivo terapötik etkileri araştırıldı.

Gereç ve Yöntemler: Kremler, Design Expert yazıımı tarafından optimize edilen basit karıştırma işlemi ile formüle edildi. Daha sonra pH, deri difüzyon profili, kısa süreli stabilite, kalitatif tayin ve yeni valide edilmiş UV-Vis spektrofotoskopi yöntemi kullanılarak ürünlerin kantitatif miktar tayini gibi özellikleri değerlendirildi. En iyi ürünlerin tavşanlarda in vivo etkinlik testi, piyasadaki Phenergan ${ }^{\circledR}$ (prometazin \%2) ile karşılaştırıldı.

Bulgular: Hem deksametazon hem de klorfeniramin miktarını eșzamanlı olarak belirlemek için UV-Vis yöntemi başarıyla geliștirildi ve valide edildi. DoE yöntemini kullanarak, deksametazonun salım profilinin, sodyum lauril sülfat, propilen glikol ve DMSO miktarına bağlı olduğu açıktı. Oysa klorfeniramin salınım modelini sadece DMSO etkiliyordu. Ayrıca, en iyi formülasyon yazılım tarafından optimize edildi. Ürün, deksametazon ve

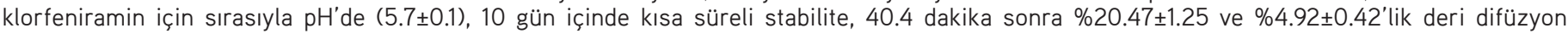
profilleri için kabul edilebilir parametreler gösterdi. Buna ek olarak, ürün, deney hayvanlarında gözlemlenebilir bir enflamatuvar tepki göstermedi. Ayrıca, satılan ürüne kıyasla 2 kat daha iyi anti-alerjik etkinlik (yani, geri kazanım süresinde 43.4 dakika ile karşılaştırıldığında 27.2 dakika) gösterdi. Sonuç: Deksametazon ve klorfeniramin içeren anti-alerjik kremin geliştirilmesi ve optimize edilmesi konusunda başarılı olduk. En iyi ürün gerekli tüm parametreleri sağlamıștır. İlginç bir șekilde, ürünümüz Phenergan ${ }^{\circledR}$ dan daha yüksek etkililik gösterdi. Bu sonuçlar, klinik araștırmalarda ileri çalışmalar için bir zemin olabilir.

Anahtar kelimeler: Deksametazon, klorfeniramin, alerjik, deney tasarımı, in vivo çalışma

*Correspondence: E-mail: pdtoan@ctump.edu.vn, Phone: +6629293832 ORCID-ID: orcid.org/0000-0002-8693-3367

Received: 23.06.2017, Accepted: 02.08.2017

-Turk J Pharm Sci, Published by Galenos Publishing House. 


\section{INTRODUCTION}

Allergy, a common disorder caused by an exposure to allergens, followed by an immune system response, can be classified into many types such as allergic rhinitis (i.e., respiratory system), asthma, drug allergy, food allergy, general allergy (i.e., pollens as allergens), insect allergy, and skin allergy. Among them, skin allergy is one of the most common types, especially in children. In 2010, in the United States of America, $10 \%$ of Asian children, $12 \%$ of white children, and $17 \%$ of African American children had skin allergies. ${ }^{1}$ Moreover, in 2012, the lifetime incidence of urticaria (i.e., hives, allergic rash) worldwide was in excess of $20 \%$ in humans. $^{2}$

The general treatments for skin allergy include anti-histamines (i.e., chlorpheniramine), glucocorticoids (i.e., dexamethasone), epinephrine (adrenaline), mast cell stabilizers (i.e., cromolyn), as well as anti-leukotriene agents (i.e., montelukast). The standard oral route of these medications encounters many unwanted averse effects. For example, the use of chlorpheniramine could lead to constipation, dizziness, headache, nausea, loss of appetite, or rarely dyskinesias, tremors, tachycardia, diplopia, dysuria, and even fatal agranulocytosis. ${ }^{3-5}$ Hence, a suitable route (i.e., local administration) should be developed. Cream formulations have been investigated intensively in recent years for skin application. Their excellent skin compatibility, high stability in normal preservative conditions, as well as ease of processability, make creams become the 'formulation of choice' for scientists.

The idea of drug combination has been proposed recently in order to reduce the dose of the individual therapeutic agents and increase the efficacy due to the synergism between the active substances. ${ }^{6-8}$ In allergy treatment, the combination of one anti-histamine, namely chlorpheniramine, and one glucocorticoid, such as dexamethasone, is often used. However, the fact that limited skin cream products containing both of these pharmaceutic agents are available in the market is undeniable. To the best of our knowledge, only one combination, namely Dexalergin ${ }^{\circledR}$, manufactured by IVAX (Argentina) is present on the market. Also, it is worth noticing that Dexalergin ${ }^{\circledR}$ has neomycin sulfate, an antibacterial agent, along with chlorpheniramine and dexamethasone (http://www. medicatione.com/?c=drug\&s=dexalergin\%20cream). Hence, no 'pure' combination of these two drugs is available.

Chlorpheniramine or chlorphenamine (Figure 1A), commonly marketed in the form of chlorpheniramine maleate, is the first generation of alkylamine compounds for anti-histamine purposes. It also possesses anti-depressant and anti-anxiety properties, although not generally approved. ${ }^{9,10}$ Chlorpheniramine's primary mechanism of action is as a histamine receptor $\mathrm{H}_{1}$ competitive antagonist, which consequently hinders the allergic response caused by histamine. On the other hand, dexamethasone (Figure $1 B$ ) is a steroid compound, which can inhibit the formation of inflammatory and allergic mediators such as histamine, prostaglandins, as well as leukotrienes.

With all these reasons taken together, we came up with the idea of the development and pre-clinical study of an anti-allergic cream containing dexamethasone and chlorpheniramine. The research was conducted using the first step of experimental design and optimization to select the best formulation, followed by quantitative method development and validation, characterization of the formulas (i.e., $\mathrm{pH}$, skin diffusion profile, short-term stability, qualitative, and assay), and in vivo efficacy test in rabbits.

\section{MATERIALS AND METHODS}

\section{Materials}

Standard chlorpheniramine and dexamethasone were bought from the Institute of Drug Quality Control, Ho Chi Minh City, lot numbers QT021050809 and QT013060909, with purities of $99.32 \%$ and $99.43 \%$, respectively. The chlorpheniramine and dexamethasone ingredients were imported from India and China, lot numbers 1010149 and 100505 , purity $98.7 \%$ and $99 \%$, respectively. Cetylstearyl alcohol, lot number 10099, was bought from Singapore; sodium lauryl sulfate, lot number 23263, was purchased from Indonesia. Dimethyl sulfoxide (DMSO), propylene glycol, glycerol, liquid paraffin, methanol, benzene, ethanol, chloroform, and hydrochloric acid were imported from China, all were of pharmaceutical grades. Phenergan ${ }^{\circledR}$ cream

A

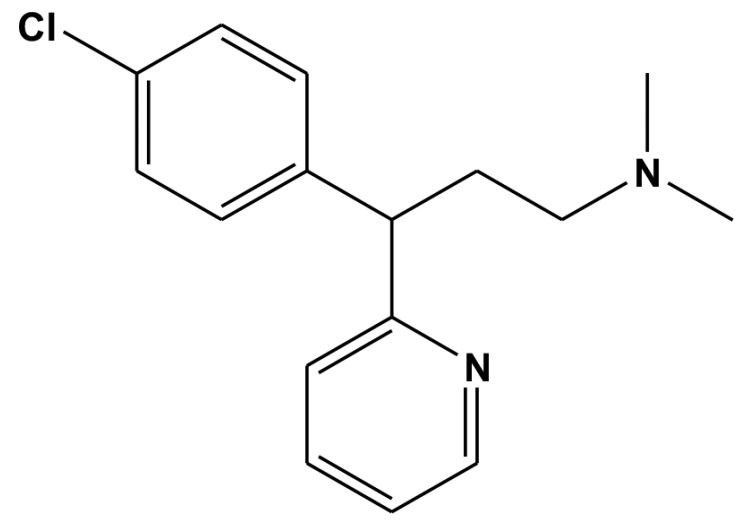

B

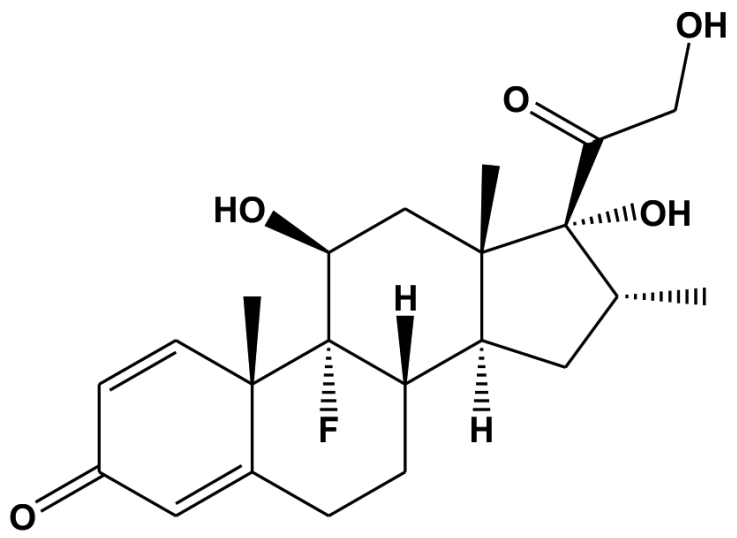

Figure 1. A) Chlorpheniramine, $\quad \mathrm{C}_{16} \mathrm{H}_{19} \mathrm{ClN}_{2}, \quad \mathrm{MW}: 274.79$, 3-(4-chlorophenyl)-N,N-dimethyl-3-(pyridin-2-yl) propan-1-amine. B) Dexamethasone, $\mathrm{C}_{22} \mathrm{H}_{29} \mathrm{FO}_{5}$, MW: 392.46, (8S, 9R, 10S, 11S, 13S, 14S, 16R, 17R)-9-fluoro-7,8,11,12,13,15,16,17-octahydro-11,17-dihydroxy-17-(2hydroxyacetyl)-10,13,16-trimethyl-6H-cyclopenta[a]phenanthren-3

$(9 \mathrm{H}, 10 \mathrm{H}, 14 \mathrm{H})$-one 
(promethazine 2\%, Sanofi-Aventis) was bought from a $\mathrm{Ngoc}$ Anh drugstore, Can Tho, Vietnam. Mature rabbits were supplied by the Department of Pharmacology, Can Tho University of Medicine and Pharmacy. Ethical approval was granted by the Ethics Committee (No: CTU 2016-5-017), based on the Animal Care and Use Committee guideline of the same university.

\section{Drug quantitation}

To determine the amount of drug either in the formulations or the release medium, we developed and validated a ultraviolet/ visible spectrometry (UV-Vis) spectrophotoscopic method that could measure both chlorpheniramine and dexamethasone under the same conditions. The samples were dissolved in methanol and were measured at the wavelengths of $239 \mathrm{~nm}$ and $262 \mathrm{~nm}$ for dexamethasone and chlorpheniramine, respectively. All validation values, including specificity, linearity, precision, and accuracy were determined using a UV-Vis spectrophotometer (Hitachi U2800, Japan).

\section{Formulation}

The formulations were produced following a simple mixing process. The oil phase, which was composed of cetylstearyl alcohol and liquid paraffin, was heated to approximately $70^{\circ} \mathrm{C}$. Then, it was mixed with the water phase, which comprised water, glycerol, sodium lauryl sulfate at the same temperature, using a high-speed homogenizer (Ultra Turrax T-25, IKA, Germany) to make the cream base. Chlorpheniramine in water and dexamethasone in propylene glycol and DMSO were then added and mixed with the cream base. The final product had the concentrations of chlorpheniramine and dexamethasone of $1 \%$ $\mathrm{w} / \mathrm{w}$ and $0.1 \% \mathrm{w} / \mathrm{w}$, respectively.

\section{Experimental design}

The Design-Expert software (version 10.0, Stat-Ease, Inc., Minnesota, U.S.A.) was used to design and optimize the formulation. The response surface methodology with the linear function model was chosen for the development part. Three independent factors, including the amount $(\mathrm{g})$ of sodium lauryl sulfate $\left(X_{1}\right)$, propylene glycol $\left(X_{2}\right)$, and DMSO $\left(X_{3}\right)$. The concentrations of two active compounds as well as other excipients such as cetylstearyl alcohol, liquid paraffin, and glycerol, were kept constant. Three factors were studied at five different levels $(-\alpha,-1,0,+1,+\alpha)$ using a central composite design. The $\alpha$ value of 1.68 was chosen to maintain the rotatability and orthogonality of the design. Two response variables were clarified, namely the percentage of in vitro release of dexamethasone $\left(Y_{1}\right)$ and chlorpheniramine $\left(Y_{2}\right)$ through the rabbit skin after $40 \mathrm{~min}$. The predicted function can be defined as follows:

$$
Y=b_{0}+b_{1} X_{1}+b_{2} X_{2}+b_{3} X_{3}
$$

where $Y$ is the predicted response, $X_{1}, X_{2}, X_{3}$ are the independent factors, $b_{0}$ is the intercept, and $b_{1}, b_{2}, b_{3}$ represent linear coefficients.

Analysis of variance (ANOVA) was used to calculate the significance of the model, and $p$ values of less than 0.05 were considered significant. The optimal formulation was also predicted using the software.

\section{Characterizations}

\section{Physical characteristics}

The appearance of the final product was evaluated by the naked eye. The suitable formulation must possess a white soft creamy texture with no observable separation between the oil and the water phases. The formulation $\mathrm{pH}$ was determined as follows: weigh $5 \mathrm{~g}$ cream and mix with $50 \mathrm{~mL}$ of distilled water for 5 min, and measure the $\mathrm{pH}$ (Mettler Toledo, Switzerland) of the filtrate of the mixture after filtration. The acceptable $\mathrm{pH}$ is in the range of 5.5 to 6 .

\section{Short-term stability}

To test the stability of the formulation, an acceleration study was conducted. The final product was kept at $40^{\circ} \mathrm{C}$ for ten days, with 2 hours of $50^{\circ} \mathrm{C}$ incubation each day. The criteria included the appearance, texture, color, and smell.

\section{Skin diffusion profile}

The end points of skin diffusion tests were evaluated using the Franz cell method. In brief, $200 \mathrm{mg}$ of the final product was weighed and applied to the rabbit skin with an area of $3.14 \mathrm{~cm}^{2}$ in the donor chamber. The acceptor chamber was filled with $18 \mathrm{~mL}$ of methanol and stirred with magnetic bars. The system was maintained at $37^{\circ} \mathrm{C}$ using a water bath. After $40 \mathrm{~min}$, the amounts of chlorpheniramine and dexamethasone released into the acceptor chamber were measured by validated using UVVis spectrophotoscopy.

\section{Drug identification}

Thin layer chromatography (TLC) was used to identify both drugs (i.e., chlorpheniramine, dexamethasone) in the cream products. The reference (i.e., standard drugs) and the samples were dissolved and extracted, respectively, in methanol for $60 \mathrm{~min}$. Ten microliters of the two samples, including the reference and the test, were applied onto the chromatography layers (Silica gel GF254, Merck, Inc., U.S.A). The mobile phase was composed of benzene - ethanol - $\mathrm{NH}_{4} \mathrm{OH}$ (85:15:1 $\mathrm{v} / \mathrm{v} / \mathrm{v}$ ). The best components and ratio of the mobile phase were preliminarily investigated based on the polarity of both compounds. The spots were visualized under UV light at the wavelength of $254 \mathrm{~nm}$.

\section{Assay}

To determine the amount of drugs in the cream product, $1 \mathrm{~g}$ of the cream (equivalent to $10 \mathrm{mg}$ of chlorpheniramine and 1 $\mathrm{mg}$ of dexamethasone) was weighed, extracted with methanol for $60 \mathrm{~min}$, and filtered through $0.22-\mu \mathrm{m}$ millipore filters (Merck, Inc., U.S.A.). The samples were then underwent UV spectrophotoscopy measurements using a validated method with methanol as a blank sample. The percentage of drugs was calculated as follows:

$\%$ Dexamethasone $=\frac{C_{1} \times 434.5 \times 10^{3}}{1 \times 99 \%} \times 100$

$\%$ Chlorpheniramine $=\underline{\mathrm{C}_{2} \times 390.87 \times 10^{3}}$

$10 \times 98.7 \%$ 
where $\mathrm{C}_{1}$ and $\mathrm{C}_{2}$ are the concentrations of dexamethasone and chlorpheniramine, respectively.

In vivo tests

\section{Inflammatory response}

Inflammatory responses of the cream products were evaluated using rabbits. Mature rabbits (weight $\geq 2 \mathrm{~kg}$ ) were cultivated in normal conditions 5 days prior testing. For the duration of 4 hours, the cream samples $(0.5 \mathrm{~g}$ ) and the control (i.e., cream base) were applied onto hair-free areas on the rabbits backs, with an area of approximately $10 \mathrm{~cm} \times 15 \mathrm{~cm}$, at $25 \pm 3^{\circ} \mathrm{C}, 30-70 \%$ humidity, and light-dark intervals of 12 hours. The remaining creams were then washed off, and skin inflammation was observed at 1, 24, 48, and 72 hours afterwards. A score, ranging from 0-0.5 for no significant inflammatory response, to 3.54.0 for serious inflammatory response (i.e., redness, swelling, animal pain) was given for each corresponding reaction, and compared with the control and the blank area (i.e., no treatment). The experiment was performed in triplicate, and the degrees of inflammatory reaction of the product were recorded and averaged.

\section{Efficacy test}

The efficacy test of the cream, in comparison with the marketed Phenergan ${ }^{\circledR}$ (promethazine $2 \%$ ) was performed similarly to the inflammatory response test. The chloroform-induced allergy model was used. One milliliter of chloroform was applied, using soft tissues, onto the hair-free areas ( 6 squares, $2.5 \mathrm{~cm}$ $x 2.5 \mathrm{~cm}$ ) for 40 seconds. Then, samples including (a) negative control; (b) cream, $0.05 \mathrm{~g}$; (c) cream, $0.1 \mathrm{~g}$; (d) positive control; (e) Phenergan ${ }^{\circledR}, 0.05 \mathrm{~g}$; (f) Phenergan ${ }^{\circledR}, 0.1 \mathrm{~g}$, were applied (Figure 2). The efficacy test ran for one hour and the time until the rabbit skin returned to normal (i.e., the recovery time) was compared with the negative control and recorded. The experiment was repeated ten times, with ten different rabbits, and the time average values were reported. Student's t-test was used to compare the significant differences between our products and the marketed Phenergan ${ }^{\circledR}$.

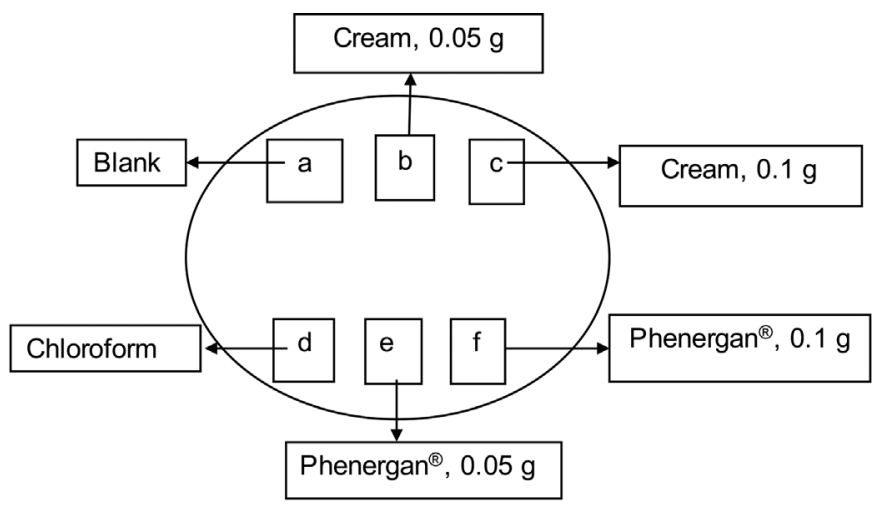

Figure 2. Diagram of drug applicable areas on the rabbit hair-free skin

\section{RESULTS AND DISCUSSION}

\section{Drug quantitation}

The concentrations of both active substances were measured simultaneously in the same samples using two different wavelengths, $239 \mathrm{~nm}$ for dexamethasone and $262 \mathrm{~nm}$ for chlorpheniramine. Due to the fact that these two substances have absorbance values at both wavelengths, and the range of the two wavelengths is more than $10 \mathrm{~nm}$ (i.e., $23 \mathrm{~nm}$ ), we calculated the concentrations based on the following equations:

$A_{\left(\lambda_{1}\right)}=\varepsilon_{\lambda_{1}}^{1} C_{1}+\varepsilon_{\lambda_{1}}^{2} C_{2}$

$A_{\left(\lambda_{2}\right)}=\varepsilon_{\lambda_{2}}^{1} C_{1}+\varepsilon_{\lambda_{2}}^{2} C_{2}$

where $A_{1}$ and $A_{2}$ are the absorbance values at $239 \mathrm{~nm}$ and $262 \mathrm{~nm} ; \varepsilon_{\lambda_{2}, \varepsilon^{1}}{ }_{\lambda_{1}, \varepsilon}^{1}{ }_{\lambda_{2},{ }^{\prime}} \varepsilon_{\lambda_{2}}^{2}$ are the molar absorptivity of the chlorpheniramine and dexamethasone at $239 \mathrm{~nm}$ and 262 $\mathrm{nm}$, respectively; and $\mathrm{C}_{1}$ and $\mathrm{C}_{2}$ are the concentrations of chlorpheniramine and dexamethasone.

By calculating from the standard samples, the $\varepsilon_{\lambda_{2}}^{1}, \varepsilon^{2}{ }_{\lambda_{1}}, \varepsilon^{1}{ }_{\lambda_{2}}{ }^{,} \varepsilon^{2}{ }_{\lambda_{2}}$ values were determined as 4336.0, 16260.8, 5351.6, and 8608.7, respectively.

The specificity was confirmed by the perfect overlay of the standard and the test samples spectra (data not shown). Moreover, the ratio of absorbance values between the blank (i.e., methanol) and the test samples was less than 1\% (i.e., $0.57 \%$ at $239 \mathrm{~nm}$ and $0.51 \%$ at $262 \mathrm{~nm}$ ), indicating the sensitivity of the method.

The linearity of the method was also specified (Figure 3). These two substances showed linearity in the range of 0-70 ppm for chlorpheniramine and 0-7 ppm for dexamethasone with coefficients of determination $\left(R^{2}\right)$ at their corresponding maximal absorption wavelengths of 0.9993 and 0.9981, respectively. The linearity of these two was also seen in the other wavelength (i.e., $239 \mathrm{~nm}$ for chlorpheniramine) (data not shown).

In the precision test, six independent samples containing both chlorpheniramine and dexamethasone were prepared and measured. The relative standard deviations (SDs) of $0.37 \%$ for chlorpheniramine and $1.59 \%$ for dexamethasone, which is less than $2 \%$, indicated the precision of the method. In addition, the
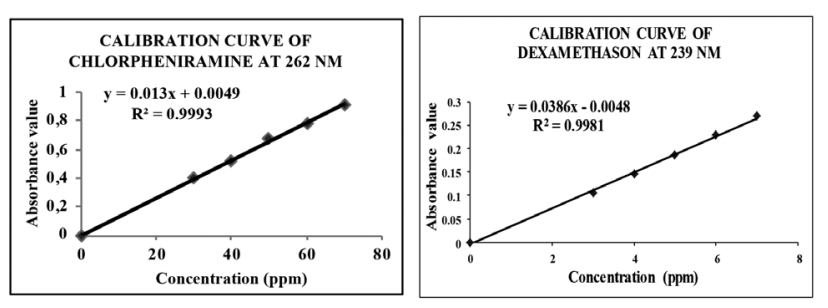

Figure 3. Calibration curves of chlorpheniramine and dexamethasone at their maximal absorption wavelengths 
recovery values of these two substances at the concentrations of $80 \%, 100 \%$, and $120 \%$ compared with the standard ones, were in the range of $98-102 \%$, which demonstrated the method accuracy. In summary, the quantitative method was validated and satisfied all required parameters.

\section{Experimental design}

From the Design-Expert software, a total of 20 formulations were proposed, formulated, and evaluated in terms of in vitro release $(\%)$ of dexamethasone $\left(Y_{1}\right)$ and chlorpheniramine $\left(Y_{2}\right)$ through the rat skin after $40 \mathrm{~min}$. The optimal correlations are shown as follows:

$Y_{1}=3.9325+0.3375 X_{1}+0.5025 X_{2}+0.71 X_{3}$

$Y_{2}=3.9325+0.30125 X_{3}$

where $X_{1}, X_{2}, X_{3}$ are the amount $(g)$ of sodium lauryl sulfate, propylene glycol, and DMSO, respectively.

The regression model was tested using ANOVA. The high $F$ values of 215.05 and 145.63 for equation (1) and (2), respectively, as well as the low $p$ values of less than 0.0001 for both equations, indicate the statistical significance of the model. Moreover, the insignificances of the lack of fit values with $p=0.473$ and $p=0.359$ clearly demonstrate that the model fitted well. These confirm the reliability of this model.

From the equations, it is likely that the fact that the release profile of dexamethasone $\left(Y_{1}\right)$ was positive linearly depended on the amount of sodium lauryl sulfate, propylene glycol, and DMSO. In contrast, only DMSO affected the release pattern of chlorpheniramine $\left(\mathrm{Y}_{2}\right)$ in a similar manner. This can be explained by the extremely low solubility of dexamethasone in water 0.1 $\mathrm{mg} / \mathrm{mL}$ ), which led to the help of surfactant (i.e., sodium lauryl sulfate) and organic solvents in its dissolution and penetration through the rabbit skin." On the other hand, chlorpheniramine, which has a water solubility at $160 \mathrm{mg} / \mathrm{mL}, 1600$ times higher than that of dexamethasone, needed only DMSO to pass through the same skin (http://www.hmdb.ca/metabolites/HMDB01944).

Optimal conditions were determined based on the correlations between these factors, with the desired limits as to maximize the percentage of drug penetrated through the rat skin after 40 min, as well as to keep the concentrations of surfactant and organic solvents at acceptable values. Based on the literature, the concentrations of sodium lauryl sulfate, propylene glycol, and DMSO in the skin cream should be less than $1 \%, 30 \%$, and $50 \%$, respectively, in order to prevent dermatitis and other kinds of skin damage..$^{12-16}$ The optimal formulation was then prepared and further studied.

\section{Characterizations}

\section{Physical characteristics}

The appearance of the optimized product possessed a white soft creamy texture with no observable separation between the oil and the water phases. The formulation $\mathrm{pH}$ was $5.7 \pm 0.1$, which was within the acceptable $\mathrm{pH}$ range of 5.5 to 6 .

\section{Short-term stability}

The acceleration test was conducted with the final products over
10 days. After this duration, all formulations exhibited excellent stability without any significant changes in term of appearance, texture, color, and smell.

\section{Skin diffusion profile}

The Franz cells method was used to evaluate the diffusion profile of the product. Rabbit skin was used due to its reproducibility property. The optimal release profiles of dexamethasone and chlorpheniramine were $20.47 \pm 1.25 \%$ and $4.92 \pm 0.42 \%$ (mean $\pm \mathrm{SD}, \mathrm{n}=3$ ), respectively, after $40 \mathrm{~min}$ of application. The relationship between the formulation ingredients and the skin diffusion (i.e., release) profiles of these two substances were optimized in the experimental design part.

\section{Drug identification}

TLC pictures of the two active substances, using benzene ethanol $-\mathrm{NH}_{4} \mathrm{OH}(85: 15: 1 \mathrm{v} / \mathrm{v} / \mathrm{v})$ as a mobile phase, are illustrated in Figure 4. Clearly, the optimal cream product demonstrates a suitable separation of dexamethasone and chlorpheniramine, with no observable interference.

\section{Assay}

Following the procedure in the method section, the concentrations of dexamethasone and chlorpheniramine in the optimal product were $100.6 \pm 0.84 \%$ and $99.9 \pm 0.37 \%$ (mean \pm SD, $n=3$ ), respectively. These results indicated that the final product satisfied the quantitative requirement for both substances.

\section{In vivo tests}

\section{Inflammatory response}

No significant inflammatory response was encountered under the experimental conditions stated in the method section. The final product demonstrated good compatibility with the rabbit skin, without any redness, swelling, or observable reactions, compared with the control groups. The average score for three

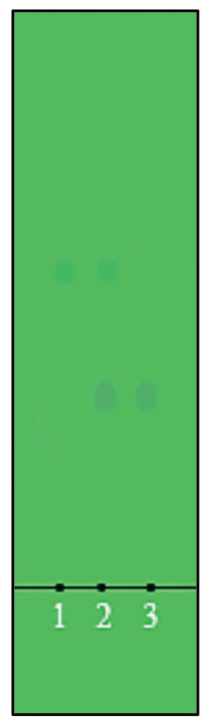

Figure 4. Thin layer chromatogram of the final cream product. (1) Standard dexamethasone, (2) Test sample, (3) Standard chlorpheniramine. Mobile phase: benzene - ethanol - $\mathrm{NH}_{4} \mathrm{OH}$ (85:15:1 $\mathrm{v} / \mathrm{v} / \mathrm{v}$ ). Dots were visualized under ultraviolet $254 \mathrm{~nm}$ 
independent tests was 0 , which is in the range of 'no significant inflammatory response' (i.e., 0-0.5). Hence, we could conclude that our product showe no irritation on the skin.

\section{Efficacy test}

Preliminary studies for the induction dose and time of chloroform to obtain an allergic response were conducted. We found that 1 $\mathrm{mL}$ of chloroform in 40 seconds was the best option. The same dose at 60 seconds could induce irreversible ulceration, which is not a good choice for an anti-allergic study. Moreover, the effects of chloroform were insignificantly different amongst the rabbit skin areas (Figure 5).

The efficacy of our cream, in comparison with the marketed Phenergan ${ }^{\circledast}$ (promethazine 2\%) in reducing the allergic response in rabbits was evaluated, in terms of recovery time (i.e., the necessary time required for the rabbit skin to recover after chloroform exposure). The results are demonstrated in Figure 6. In brief, similar to Phenergan ${ }^{\circledR}$, our cream was a dosedependent product, with a significant 2-fold shorter recovery time in the $0.1 \mathrm{~g}$ dose $(27.2 \pm 1.42 \mathrm{~min})$ compared with the $0.05 \mathrm{~g}$ dose $(55.8 \pm 1.54 \mathrm{~min})(p<0.05, n=10)$. Interestingly, our optimal product showed meaningfully better therapeutic effects (i.e.,

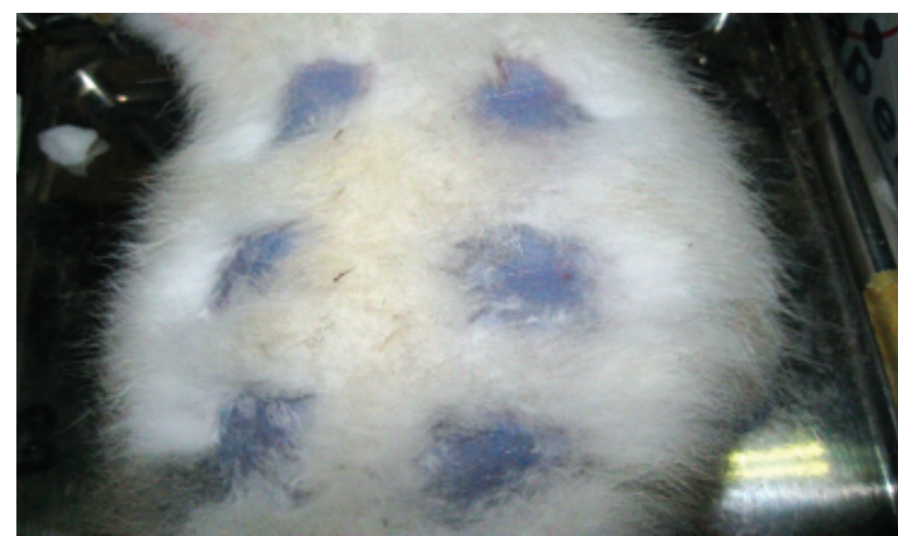

Figure 5. Chloroform-induced allergy model. One milliliter of chloroform solution for $\mathbf{4 0}$ seconds could induce the allergic response similarly amongst the rabbit skin areas

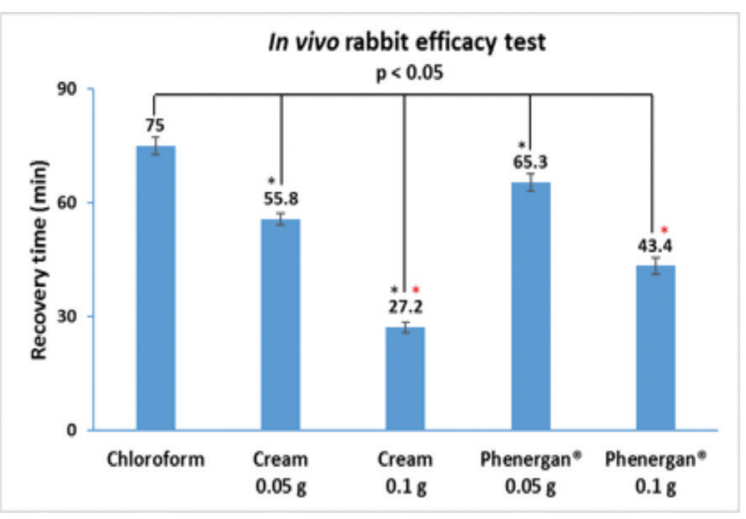

Figure 6. In vivo rabbit efficacy test, in the comparison between the optimal cream and the marketed product Phenergan ${ }^{\circledast}$. The results are demonstrated as mean \pm standard deviation, $n=10$. The black line indicates the significance $(p<0.05)$ between the negative control chloroform and the formulations. The black and red stars show the differences between the doses and the formulations ( $p<0.05)$ lower recovery time) than the marketed product Phenergan ${ }^{\circledR}$ at both doses ( $p<0.05, n=10$ ). This could be due to the synergistic effect of dexamethasone and chlorpheniramine. Finally, the use of a combination product (i.e., more than one active substance in a product) might reduce the dose of each individual substance, and hence, hinder unwanted effects.

\section{CONCLUSION}

In summary, anti-allergic cream containing dexamethasone and chlorpheniramine was successfully prepared, optimized, characterized, as well as evaluated in in vitro and in vivo test. The optimal formulation was considered a novel formula, which balanced the efficacy and toxicity of the product, regarding organic solvents such as propylene glycol and DMSO. Additionally, our product satisfied all of the evaluation parameters (i.e., physical properties, stability, skin diffusion profiles, drug identification, assay, toxicity, and efficacy). This product, which showed a potentially better therapeutic effect in comparison with the marketed Phenergan ${ }^{\circledR}$, has been further developed and is undergoing clinical trials in our laboratory. Our ideas and research could be applied in other pharmaceutical products to enhance the development of inexpensive medicines for developing countries.

\section{ACKNOWLEDGEMENTS}

DT Pham wishes to sincerely thank the Department of Pharmacology, Faculty of Pharmacy, Can Tho University of Medicine and Pharmacy, for supporting the animals and providing necessary help. The authors also appreciate the cooperation of senior pharmacy students.

Conflict of Interest: No conflict of interest was declared by the authors.

\section{REFERENCES}

1. Bloom B, Cohen RA, Freeman G. Summary health statistics for U.S. children: National Health Interview Survey, 2010. Vital Health Stat 10. 2011;250:1-80.

2. Pawankar R, Canonica GW, Holgate ST, Lockey RF. World Health Organization. White Book on Allergy 2011-2012 Executive Summary; 2012.

3. Schuller DE, Turkewitz D. Adverse effects of antihistamines. Postgrad Med. 1986;79:75-86.

4. Simons FE, Simons KJ. Histamine and H1-antihistamines: celebrating a century of progress. J Allergy Clin Immunol. 2011;128:1139-1150.

5. Mahdy AM, Webster NR. Histamine and antihistamines. Anaesthesia Intensive Care Medicine. 2017;18:250-255.

6. Tallarida RJ. Drug Synergism: its detection and applications. J Pharmacol Exp Ther. 2001;298:865-872

7. Feala JD, Cortes J, Duxbury PM, Piermarocchi C, McCulloch AD, Paternostro G. Systems approaches and algorithms for discovery of combinatorial therapies. Wiley Interdiscip Rev Syst Biol Med. 2010;2:181193.

8. Lehar J, Krueger AS, Avery W, Heilbut AM, Johansen LM, Price ER, Rickles RJ, Short GF 3rd, Staunton JE, Jin X, Lee MS, Zimmermann GR, 
Borisy AA. Synergistic drug combinations tend to improve therapeutically relevant selectivity. Nat Biotechnol. 2009;27:659-666.

9. Carlsson A, Lindqvist M. Central and peripheral monoaminergic membranepump blockade by some addictive analgesics and antihistamines. J Pharm Pharmacol. 1969;21:460-464.

10. Gruetter CA, Lemke SM, Anestis DK, Szarek JL, Valentovic MA. Potentiation of 5-hydroxytryptamine-induced contraction in rat aorta by chlorpheniramine, citalopram and fluoxetine. Eur J Pharmacol. 1992;217:109-118.

11. O'Neil MJ. The Merck Index - An Encyclopedia of Chemicals, Drugs, and Biologicals (13 ${ }^{\text {th }}$ ed). Whitehouse Station, NJ: Merck and Co Inc; 2001:518.

12. Wigger-Alberti W, Krebs A, Elsner P. Experimental irritant contact dermatitis due to cumulative epicutaneous exposure to sodium lauryl sulphate and toluene: single and concurrent application. $\mathrm{Br} \mathrm{J}$ Dermatol. 2000;143:551-556.

13. Eubanks SW, Patterson JW. Dermatitis from sodium lauryl sulfate in hydrocortisone cream. Contact Dermatitis. 1984;11:250-251.

14. Kuznetsov AV, Erlenkeuser-Uebelhoer I, Thomas P. Contact allergy to propylene glycol and dodecyl gallate mimicking seborrheic dermatitis. Contact Dermatitis. 2006;55:307-308.

15. Lowther A, McCormick T, Nedorost S. Systemic contact dermatitis from propylene glycol. Dermatitis. 2008;19:105-108.

16. Willhite CC, Katz PI. Toxicology updates: dimethyl sulfoxide. J Appl Toxicol. 1984:4:155-160. 